\title{
Using Free Online Readings to Teach Introduction to American Government
}

\author{
Chelsea N. Kaufman \\ Department of History and Political Science \\ Wingate University
}

\begin{abstract}
Several studies have examined using electronic textbooks as compared to print textbooks, or open educational resources (OER) compared to commercial textbooks. Fewer studies, however, examine the use of free or low-cost online readings that are not an OER textbook or assigned in conjunction with a textbook. In my introductory American Government course, all assigned course readings were items that students could access for free online or through the university library. The use of these free or low-cost materials should have provided similar benefits to students as the adoption of an OER textbook typically would, namely cost savings. At the same time, they could have drawbacks similar to OERs and electronic textbooks, such as students having difficulty finding information within the text or accessing materials if they do not have home Internet access. Furthermore, this approach required more preparatory work for the instructor. Based on a survey of my students in the course, I found that students had positive evaluations of the course materials and recommended that they be used in future courses. As expected, their overall assessments were similar to those of electronic textbooks and OERs.
\end{abstract}

Keywords: TLC2020, The Virtual Classroom, OER

Prepared for presentation at the American Political Science Association Teaching and Learning Conference, February 7-9, 2020, Albuquerque, NM 


\section{Introduction}

Selecting course materials that engage students and provide students with accessible information on the topic can be a challenge, especially if the instructor is also trying to be conscious of the cost of these materials. In my introductory American Government class, students were assigned a set of readings made available online for each topic of the course instead of a traditional textbook. The materials are either freely available or can be accessed without additional cost for students through the university library. For example, these may include historic documents archived online such as The Federalist Papers or short articles or blog posts written by experts, such as in The Monkey Cage. Additionally, they were required to participate in interactive polls using the iClicker application or remote.

The intent of using these materials was to provide a low-cost way for students to have access to the materials and engage in the course. Using a survey of the enrolled students, I examined whether they agreed that these materials were low-cost, engaging, and helpful in achieving the course objectives. Additionally, I examined factors such as their demographic characteristics and their performance in the course to determine how beneficial the use of these materials was to various groups of students. Based on past research concerning open educational resources (OERs) and electronic textbooks (e-books), my expectations were that students would appreciate the cost savings, but that some might find it difficult to navigate or access the online materials. I also expected that students would have positive evaluations of the iClickers and report being more likely to engage in class.

\section{Overview of the Course \& Materials}

During the fall semester of 2019, I made use of the iClicker technology and free readings in an introductory American Government course at Wingate University. Wingate University is a private-nonprofit comprehensive university with 3,689 undergraduate students. Costs may be a concern for many students, with 48 percent of full-time beginning undergraduates receiving Pell 
grants and 63 percent of them receiving federal student loans (National Center for Education Statistics, 2019). Of the students surveyed in this course, $57.9 \%$ (11 students) reported that they had in the past decided not to purchase course materials due to their cost, and one student reported that they do not usually buy any course materials ${ }^{1}$. One section of this particular course is currently offered annually in the fall semester. There were 22 total students enrolled during the Fall 2019 semester. Most students enrolled were required to take the course for their major, such as Political Science, History, or Education. The course objectives are as follows:

- Understand the function of political institutions in the United States and how they have changed throughout history

- Understand how forces such as societal and cultural changes, historical events, and political thought have shaped these institutions and their changes

- Understand how the people interact with these institutions in the context of culture, history, and current events and policy debates

All course materials, including assignments, quizzes, examinations, lecture slides, and readings are posted on Canvas, the Learning Management System (LMS). Students are expected to access these on their own to prepare for class and submit work through the LMS. The only exception to this is the use of "minute papers," which are administered in class during weeks where there are quizzes (for a review of the use of minute papers, see Stead, 2005). At the beginning of the week, they write down what they know about the topic and what they want to know. At the end of the week, they summarize what they have learned and pose any questions they still have. I respond to these questions on a page on Canvas for the benefit of all students and also use these papers to gauge whether students have achieved the week's learning objectives or if there is a common need to review certain points. Therefore, while the

\footnotetext{
1 This student also did not purchase access to the iClicker polls and was required to complete the polls on
} paper and submit them to me at the end of each class session. 
course is face-to-face, I heavily use online resources to facilitate its administration and provide resources to students.

I use a variety of methods to assess student performance. These include the following items:

- 10 one-page written assignments based on the course readings, typically due before class on Fridays to facilitate class discussion of the readings ( $15 \%$ of final grade)

- 10 multiple-choice quizzes on the week's topic, covering content from readings or lecture, due at the end of each week, which students completed through the LMS (8\% of final grade)

- 3 examinations consisting of multiple-choice and short answer questions, which are open notes/open book and students completed through the LMS (45\% of final grade)

- A final project and presentation on a public policy issue in the state of North Carolina, which is a group project broken down into several graded components ( $25 \%$ of final grade)

- Participation in class discussion and completion of the minute papers ( $7 \%$ of final grade) The key aspects of the course being discussed here are its use of the interactive iClicker polling technology and its use of "free" online materials as course readings rather than a traditional textbook. This means that the only item students must purchase for the course is access to the polling software, keeping the cost low. Although they were not assigned a textbook, students were advised to use OERs available online such as the American Government textbook published by OpenStax (Krutz and Waskiewicz, 2019) or other resources available for free online, such as the Crash Course US Government and Politics YouTube video series (Crash Course, 2016) if they needed additional information. All these materials were listed in the course syllabus, including URLs, and students could also directly access them through the LMS. 


\section{Evaluating the Use of Electronic or Open Education Resources}

Although use of interactive polling and non-textbook readings are not novel concepts, the latter has little research on its effectiveness in the classroom. Instead, most research focuses on OERs as compared to traditional textbooks or electronic textbooks (e-books) as compared to print textbooks. These are somewhat different from the approach used in this course because not all materials were OER (such as those requiring newspaper subscriptions) and, consequently, the materials were not organized into a single textbook assigned for the course. However, because the course uses free readings that are available online, I expect student views of these readings and learning outcomes to be similar to those concerning e-books or OERs due to these common characteristics.

There is more extensive research concerning the use of interactive polling. Research on the use of interactive in this particular class (Introduction to American Government) indicates that students had a positive experience with these (Evans 2012; Ulbig and Notman 2012). They are overall more satisfied with the course and perform better than students who do not use polls. Students who are shy are especially likely to benefit (Ulbig and Notman 2012). The use of polls is not the main focus of the present study, but students were surveyed on these as well in order to gain a complete understanding of how they evaluate the course materials and to see if the same results are found. My expectation is that the students' viewpoints concerning the polls will be similar to what was found in these studies.

There is some research that focuses on the use of free, online materials as course readings. Allen (2016) specifically examines the use of blogs to supplement textbook readings. He finds that students who read professional political science increased their exam performance over students who did not read these blogs. However, the author's students also had assigned readings from a print textbook. Lawrence and Lester (2018) examine the effectiveness of using OERs in their Introduction to American Government class, specifically a textbook that is freely 
available online (students may also obtain print copies). They found that student performance was slightly worse but felt that these were outweighed by the cost benefits. Kalaf-Hughes (2019) also examined the use of an OER in an Introduction to American Government class. She did not find significant differences in performance or student evaluation of the text compared to use of a traditional textbook, but did find that students who were less interested in the course were more engaged with the OER, while students who were more interested were less engaged. Brandle (2018) developed an OER sourcebook for an Introduction to American Government class. Similar to the approach in my course, this OER sourcebook made use of original sources, such as the Constitution, but for topics where appropriate sources of this nature were not available, the course also used freely available online materials such as the Crash Course YouTube series. Her analysis found that students performed worse on examinations using the sourcebook as compared to another OER, felt that there was too much reading assigned and that the reading was too challenging. Students performed better in the portions of her course where links to external websites were provided rather than the original historical documents, which was the case for most topics in my course. Therefore, although students in my course were not be required to reference an OER for readings, my expectations are derived from these studies: there may be some drawbacks, but cost savings and the ability to engage certain students should outweigh these.

What could these potential drawbacks be? Lawrence and Lester (2018) found that students felt that it was difficult to find information in the text and that students had lower performance. Brandle (2018) also observed lower student performance. Additionally, student evaluations of the materials are not always positive. Students tend to prefer print textbooks, especially when the readings are long (Mizrachi, 2014). They feel the same regardless of their past experience with computers or e-textbooks (Woody, Daniel, and Baker 2010). Brandle (2018) reported dissatisfaction with reading long, historical documents in her OER sourcebook, and KalafHughes (2019) reported similar student comments concerning print vs. e-books. Therefore, 
students may perform worse due to difficulty navigating the material or not recommend use of the materials due to dissatisfaction, regardless of their performance. Another potential issue with online readings is that students may also have difficulty completing readings and submitting related assignments if they lack Internet access at home (Anderson and Perrin 2018). This is especially the case for low-income and African American students. However, this study was conducted among students in K-12 settings. Wingate University students who do not have Internet access at home should be able to access course materials while on campus.

Demographic questions on the survey will show whether students of certain backgrounds felt more positive or more negative about this practice.

Regardless of student perceptions or performance, one positive aspect of assigning OERs or readings that are freely available can save students a significant amount of money. Previously in this course, I assigned Keeping the Republic: Power and Citizenship in American Politics, The Essentials (Barbour and Wright, 2019). The price for this book currently ranges from $\$ 54.00$ for a six-month e-book rental to $\$ 107.00$ for a new paperback copy if purchased directly through the publisher's website. Although some materials used could potentially require payment (e.g. articles in publication requiring a subscription), all of these could be accessed for free through the university library. Now, the students' only required expense is a subscription to the Reef polling app, at $\$ 15.99$ for six months' access (they may choose to purchase a remote or a longer subscription at higher cost). The cost of the app is lower per course for some students, as many other courses also use this software. Six of the students surveyed (31.6 percent) reported that they used the app in other courses as well.

The instructor must also weigh the adoption of materials of this nature from their own perspective. The textbook I previously assigned provides numerous resources to students, such as quizzes, flashcards, and study questions. Many of these resources can be directly integrated into the LMS. This means that with very little extra work from the instructor, students can have these at their fingertips to help them to review the course materials. Furthermore, many 
textbooks provide other useful resources for instructors, such as test banks or lecture slides. Some OER textbooks may provide similar resources but using a curated list of readings from disparate sources each week requires the instructor to develop examinations, lecture slides, and review materials for students on their own. The upside is that the instructor has a great deal of flexibility and control in designing these, but at the cost of a relatively large time commitment each time new materials are assigned in the course. Lawrence and Lester (2018) describe similar considerations.

\section{Data and Methods}

In order to collect the data for this analysis, I surveyed the 22 students enrolled in the course. Students were provided with half a percentage point of extra credit for responding or were allowed to complete an alternative assignment to receive the same amount of extra credit if they did not wish to complete the survey. An announcement of this was made in class during the last month of the semester, and an example of the email/Canvas announcement sent to students to recruit them is included in Figure 1. This study was approved by the Wingate University Research Review Board (RRB).

\section{Figure 1 about here}

The survey asked students questions concerning why they enrolled in the course; how interested they are in the course subject matter outside of class; what their preferences for course materials and engagement in courses are; how they used the materials for this course; what their preferences were concerning the course materials; whether they felt the materials helped them to achieve the course learning objectives; and whether they were generally satisfied with the course. Several of these questions are based on those used by others conducting similar research (Evans, 2012; Lawrence and Lester, 2018; Ulbig and Notman, 2012). They were also asked to report several personal and demographic characteristics. A complete list of questions asked is provided in the Appendix. 
A total of 19 students completed the survey. Descriptive statistics concerning these students' personal and demographic characteristics are provided in Table 1. All but one student was female, and all students were 18-24 years old. Most students were non-Hispanic white, but nearly a third of the class (31.6\%) were students of color. Most $(52.6 \%)$ were first-generation college students (neither parent completed a four-year university degree). Finally, in addition to being enrolled as students, $47.4 \%$ reported that they worked part-time. In particular, I will examine whether using low-cost, engaging materials was associated with equitable performance for students who may be academically unprepared, such as minority and firstgeneration students, as compared to other students, in accordance with research suggesting it is helpful to create a welcoming and engaging environment to help these students succeed (Gabriel, 2018).

\section{Table 1 about here}

In addition to survey responses, I analyzed data from the students' overall performance in the course along with relevant academic information. These included their overall course grade, their attendance of class sessions, their class status, and their major or minor. These data were analyzed in conjunction with their survey responses in order to determine which factors were associated with better performance in the course. Table 2 provides descriptive statistics concerning these data. I anticipate finding that students who performed better in the course had more positive views of the course materials. However, they may also have performed better in the course because they used the materials more frequently, were a later point in their college careers, or were taking a course for their Political Science major or minor.

\section{Table 2 about here}

Using the data from the survey as well as the data concerning the students' characteristics, I will explore the following research questions:

- $\quad$ Did the course materials, specifically free or low-cost online readings and clickers, help students to achieve learning objectives? 
- $\quad$ Did the course materials, specifically free or low-cost online readings and clickers, help students to engage in the course?

- Did the students prefer the course materials, specifically free or low-cost online readings and clickers, used over traditional textbooks?

- Were the course materials, specifically free or low-cost online readings and clickers, more or less helpful to students of various demographic backgrounds?

There are a few limitations to this data. One is that the survey responses rely on selfreports and self-evaluations by the students. Because the data were not collected anonymously, this may lead them to report what they perceive of as socially desirable, although the impact of this bias should be minimal, especially for students beyond their first year (Bowman and Hill, 2011; Miller, 2012). In the case that there is bias, one should focus primarily on relative relationships between the variables rather than the absolute value of the numbers reported in interpreting the results. For example, I ask whether students who report reading more perform better, rather than examine in depth the average proportion of readings completed. Furthermore, I examine their performance in the course in addition to their self-evaluation.

Another is that the class size is relatively small, and there is no other similar course section with an alternative design to compare it to. This limits the analysis to descriptive statistics and bivariate relationships. Furthermore, these factors mean that the results in my course may not apply in other contexts due to unique attributes of my course. For example, my course had only two men enrolled, and only one of these men completed the survey. The experience in my classroom may be different than in a classroom that is male-dominated or where there are more diverse gender identities. Furthermore, I cannot compare results for students with different gender identities. Additionally, of the students who completed the survey in my course, all were between the ages of 18-24. Again, this means that I cannot compare results for students of different age groups, and that the results may not be applicable to 
classrooms with students of varying ages. In short, the results I observe in the analysis of this course may not apply to others' courses where the class size is larger, or the background of the students is different in some way.

\section{Results}

Overview of Viewpoints on Course Materials

Students primarily had positive viewpionts concerning the course materials. Overall, 89.5 percent of the students agreed that they were generally satisfied with the materials with this course, and $79 \%$ agreed that they should be used for this course in the future. Looking specifically at the readings, $63.2 \%$ of the students agreed or strongly agreed that the online readings should be used instead of a traditional textbook in future courses. Similarly, $79 \%$ of students agreed or strongly agreed that the clickers should be used in future courses. The percent of students who agreed or strongly agreed with several other positive statements concerning the course readings and use of the iClickers is detailed in Table 3.

\section{Table 3 about here}

When asked about how they used the readings, however, students reported inconsistent use. The modal student $(26.3 \%$ of students) reported that they read half of the readings, and only three students reported that they read $90-95 \%$ of the readings ( $13.6 \%$ of students). Students were most likely to have said they used the readings to complete assignments, followed by review for quizzes and examinations. The use of readings for various course activities by students is reported in Figure 2. Students did not report that they instead turned to optional course materials, with only $10.5 \%$ reporting that they referenced the OpenStax textbook and $31.6 \%$ reporting that they referenced the Crash Course: US Government and Politics YouTube series.

\section{Figure 2 about here}


Students also came into the course with pre-existing viewpoints on course materials that may have affected their evaluations of the materials used in this course. One of these could be a preference for e-books or print copies of textbooks. E-books were preferred by $52.6 \%$ of students, although most students reported that they generally rent or buy a print copy textbooks ( $36.8 \%$ buy used, $26.3 \%$ rent, and $5.3 \%$ buy new). When asked the reason for their preferences, these reasons varied depending on whether the student prefered e-books or print textbooks, as detailed in Table 4. Students were allowed to select as many reasons as applied to their preference. Reasons unique to a preference for e-books were price (36.8\%) and not having to carry the book around (5.3\%). The only reason unique to a preference for a print copy was ease of understanding (26.3\%). More students also reported that they preferred print copies for ease of finding information (42.1\%), ease of notetaking (47.4\%) and ease of reading informaton (42.1\%) for print textbooks. These preferences align with findings from past reseasrch concerning e-book or print textbook preferences.

\section{Table 4 about here}

Students also had preferences about how they prefer to engage with course materials in class. For example, some students may prefer discussions (based on the readings) or polls, which could impact their preferences for the course materials. The students preferences for forms of engagement are detailed in Figure 3. Most students prefered open class discussions (78.9\%), followed by surveys or polls (57.9\%). There were 2 students (10.5\%) who indicated that they prefer lectures rather than engagement.

\section{Figure 3 about here}

\section{Factors Relating to Course Performance}

Given the positive views of the course materials, but the inconsistent use of them, one might ask how well students performed in the course. Additionally, an examination of factors relating to course performance is necessary to determine whether there were similar outcomes for 
students of various backgrounds. Figure 4 is a graphical representation of a correlation matrix examining the relationship between the students' final grades and several factors related to their academic and personal backgrounds. These included their hours worked per week; whether or not they were first generation students; whether they enrolled because the course was required; whether they were non-Hispanic white or students of color; whether they were a Political Science major or minor or not; their total number of absences; their class status (freshmensenior); their percent of readings completed; whether they enrolled in the course because they were interested or not; whether they read political blogs; whether they read political news online; and whether they discuss politics with family and friends. Stronger relationships are represented by larger circles (weaker $=$ smaller) and positive relationships are represented by darker circles (negative $=$ lighter). Circles are only displayed for relationships that were statistically significant at the $p=.10$ level.

\section{Figure 4 about here}

Several of these items were significantly related to a higher final grade in the course. Students who worked more hours per week and were absent more frequently earned lower final grades in the course. Students who read a higher percentage of the assigned reading, enrolled in the course because they were interested, more frequently read political news online, and more frequently discussed politics with their family and friends earned higher grades in the course. In short, students who were able to devote more time to the course and who were more interested in the subject matter had better performance, as one might expect. There were no statistically significant differences in final grades when comparing first generation and minority students to other students. The average grade earned in the course for students surveyed was $83.97 \%$, with a standard deviation of $9.85 \%$.

Although there is clear evidence that students who read more performed better, there was mixed evidence as to how students felt about the effect of the materials on their 
performance. Table 5 details the percent of students who agreed or strongly agreed that the course readings helped them to achieve each of the learning objectives. In each case, a majority of students reported that they were helpful. However, when asked which components of the course were most helpful to achieving the course objectives, only a few students $(21.1 \%)$ reported that the readings were helpful. They were more positive about the polls, with nearly half $(47.4 \%)$ reporting these were among the most helpful components. Students were mostly likely to have said that discussions were the most helpful component (89.5\%). A few students also felt that the polls and readings were the least helpful components (26.3\% for both items). Students were most likely to have said that the minute papers were least helpful $(57.9 \%)$. Refer to Figures 5 and 6 for complete details on which course components students felt were most or least helpful to them.

\section{Table 5 about here}

\section{Figures 5 and 6 about here}

\section{Factors Relating to Viewpoints on Course Materials}

To examine the key question of interest, whether students felt that the course materials were low-cost and engaging, I analyzed several factors relating to their general satisfaction with the materials and whether they recommended use of these materials in future courses. I also considered the relationship between satisfaction with the materials and course performance. This is a relationship that could go either way - perhaps students liked the materials because they were performing successful, or perhaps they performed successfully because they were engaged in the course. In addition to the personal and academic characteristics analyzed in relation to course performance, several additional factors relating to students' general preferences for course materials were included in this analysis. These included their general preferences for e-books as compared to print textbooks, whether cost had ever prevented them from buying a textbook, whether they had previously used the iClicker polls, and whether their preferred methods for engaging in courses included discussions and surveys or polls. 
The correlation between academic and personal characteristics and the students' general satisfaction with the materials, whether they would recommend the readings, and whether they would recommend the iClickers is displayed in Figure 7. The same factors are examined as in Figure 3, and the correlation matrix should be interpreted in the same way. Although one's status as a first-generation student was not significantly related to their course performance, it was significantly related to their general satisfaction with the course materials, with first generation students being less likely to agree that they were satisfied. Students who indicated that they were enrolled because the course was required and students who more frequently discussed politics with family and friends were more likely to recommend use of the iClickers in future courses. There were no academic or personal characteristics that were significantly related to whether the students recommended these same materials generally or specifically recommended use of the same readings in future courses. Final grades were not significantly related to the students' views of the course materials.

Figure 7 about here

The correlation between their course material and engagement preferences and the students' general satisfaction with the materials, whether they would recommend the readings, and whether they would recommend the iClickers is displayed in Figure 8. The only item that was significantly related to general satisfaction with the course materials was a preference for engagement through small group discussion. This is somewhat expected because the readings were primarily used to prepare students for small group and open class discussions. No other relationships were statistically significant.

\section{Figure 8 about here}

I also reviewed students' responses to open-ended questions concerning the used of these materials in the future. Of students who recommended continued use of the online readings instead of a traditional textbook for the course, they focused on the cost and 
engagement. The following responses ${ }^{2}$ to the open-ended questions about what they liked best about the materials demonstrate these points:

- I liked that there was no required textbook, and we were given a free online textbook as reference. I believe by making the readings optional it encourages learning based on interest instead of requirement.

- Free!!

- I did not stress about affording the materials.

- That I did not have to spend money on a textbook.

- The reading was not too complicated to process and relate back to class.

- I like that I got to understand it better with the assignments that were given.

Their views were not entirely positive, however. There were six students who felt neutral about the use of the readings in the future or disagreed with their use. Among those students, the aspects of the course materials that they liked best included discussions, the variety of materials, or the use of the iClickers. When asked what they liked least about the course materials, their comments focused on the readings being online or difficult to understand:

- Online reading and assignments.

- Some of the online readings did not explain topics clearly because they are written as if you already understand them.

- I thought that articles online weren't really read throughout the class or discussed.

- I did not like that we did not have a paper copy of the book. Although it does save money I prefer to be able to flip through the pages to find my answers.

2 Student comments have been edited for spelling and punctuation. Additionally, if a student commented on multiple aspects of the course, only the applicable portion of their response is included. 
These students who did not agree with using the materials in the future also provided similar responses when provided with an opportunity for open-ended comments or suggestions for future changes to the course:

- My only suggestion is to also include more readings that focus on a topic more broadly by explaining it rather than applying it to a specific situation/event in order for students to understand a concept better.

- I think that there should be an actual text for this class and not just articles from online.

- I loved the discussions in this class, but for the readings I would suggest putting the book on the Wingate bookstore page but leave a note saying they can choose this or the optional reading.

Among those who recommended the use of these readings in future courses, some still felt they were confusing or unclear, as evidenced by these following open-ended comments about what they liked least about the course materials:

- What I liked least about the materials is sometimes the readings for our weekly assignments were confusing.

- I felt like they weren't always streamlined.

There were fewer students who commented directly on the use of the iClicker polls. Among students who recommended the use of the clickers in future courses, students focused on their interactivity and anonymity in open-ended comments concerning what they liked best about the course materials. The following comments demonstrate these views:

- I liked the iClicker polls because it lets you express yourself without other people knowing what you answered.

- They helped me interact more in class.

- I liked the use of the clickers best about this course. 
Negative comments from students concerning the iClickers focused on cost, whether the student recommended the use of these in future courses or not:

- The price of the clicker since I am only using it once.

- I feel that the clicker should not cost, is there another way to do surveys without an extra cost to students?

- Also, the clicker is something that students have to pay additional for and its only used about once or twice during the whole class.

Some comments on what students liked least did not focus on the readings or the polls. Six students either provided no comment in response to this question or indicated that there was nothing they liked least. Several others focused on other elements of the course, such as the minute papers or examinations.

\section{Discussion}

Based on past research concerning e-books and OERs, my expectations were that students would feel that they were able to engage in the course and like that the materials were a lowcost option, but that they may have difficulty reading and understanding the materials due to there being no traditional textbook required. The results were in line with these expectations. The key conclusions of this analysis were that students had very positive evaluations of the course materials, recommended their use in the future, and appreciated that that readings were free. However, they had mixed opinions concerning whether the materials were helpful in achieving course objectives, some expressed preferences for print materials or traditional textbooks, and others expressed dissatisfaction with the fact that the iClicker software was not free. In the future I plan to pursue other free options for interactive polling, which should alleviate this concern while maintaining the benefits. 
I also plan to continue use of the free online readings in the future. Although there were some possible downsides to using these, such as some students finding them confusing, most students gave the materials positive evaluations, especially about the low cost and opportunities to become engaged and interested in the course. A quote from the anonymous course evaluations is particularly demonstrative of this point:

The course was great and added some good evidence that a good and well-rounded course can be created at a low cost for students. The information was relevant and interesting and provided real life experience on finding that info - students are not likely go back and read a chapter on critical elections, but if there's a good news article with a cool picture or colorful timeline, students will go back to it.

Furthermore, while using these materials, there were no significant differences in performance between students who were first-generation or who were students of color, who may be less academically prepared or lack sufficient internet access, which were concerns with offering readings outside of a traditional textbook, although first-generation students did report lower evaluations of the materials. The only significant differences in performance were between those who would have been more or less interested in the course subject matter and those who were able to devote more or less time to the course.

One limitation of the data was that I had a small sample size with no other course section for comparison. Continuing use of this approach in the future should allow me to continue to collect similar data in future course sections for comparison and draw broader conclusions. Although I will still be unable to perform a controlled experiment assessing the use of these materials, I will be able to track any over time changes as I make changes or improvements and perform multivariate analyses that could reveal additional insights by continuing this work in the future. 


\section{References}

Allen, Michael A. 2016. "Blog Consumption and International Relations." Journal of Political Science Education, 12(2): 169-185.

Anderson, Monica, and Andrew Perrin. 2018. "Nearly One-in-Five Teens Can't Always Finish their Homework Because of the Digital Divide." Pew Research Center Fact Tank, October 26. https://www.pewresearch.org/fact-tank/2018/10/26/nearly-one-in-five-teenscant-always-finish-their-homework-because-of-the-digital-divide/

Barbour, Christine, and Gerald C. Wright. 2019. Keeping the Republic: Power and Citizenship in American Politics, The Essentials, CQ Press.

Bowman, Nicholas, and Patrick L. Hill. 2011. "Measuring How College Affects Students: Social Desirability and Other Potential Biases in College Student Self-Reported Gains." New Directions for Institutional Research, 150: 73-85.

Brandle, Shawna. 2018. "Opening up to OERs: Electronic Original Sourcebook Versus Traditional Textbook in the Introduction to American Government Course." Journal of Political Science Education 14(4): 535-554.

Crash Course. 2016. US Government and Politics. YouTube. https://www.youtube.com/playlist?list=PL8dPuuaLjXtOfse2ncvffeelTrqvhrz8H

Evans, Heather K. 2012. "Making Politics 'Click': The Costs and Benefits of Using Clickers in an Introductory Political Science Course.” Journal of Political Science Education, 8: 85-93.

Gabriel, Kathleen F. 2018. Creating the Path to Success in the Classroom: Teaching to Close the Graduation Gap for Minority, First-Generation, and Academically Unprepared Students. Stylus Publishing.

Kalaf-Hughes, Nicole. 2019. "Reaching Students with Low Interest: Subject Matter Interest and Perceptions of Open Educational Resources in an Introductory American Government Course." Journal of Political Science Education.

Krutz, Glen, and Sylvie Waskiewicz. 2019. American Government. $2^{\text {nd }}$ Edition. OpenStax. https://openstax.org/details/books/american-government-2e

Lawrence, Christopher N., and Julie A. Lester. 2018. "Evaluating the Effectiveness of Adopting Open Educational Resources in an Introductory American Government Course." Journal of Political Science Education, 14(4): 555-566.

Miller, Angie L. 2012. "Investigating Social Desirability Bias in Student Self-Report Surveys." Educational Research Quarterly, 36(1): 30-47.

Mizrachi, Diane. 2014. "Online or Print: Which do Students Prefer?" European Conference on Information Literacy: 733-742.

National Center for Education Statistics. 2019. "Wingate University." College Navigator. https://nces.ed.gov/collegenavigator/?q=wingate+university\&s=all\&id=199962\#finaid 
Sage Publishing. 2019. "Keeping the Republic: Power and Citizenship in American Politics, The Essentials." https://us.sagepub.com/en-us/nam/keeping-the-republic/book259168

Stead, David R. 2005. "A Review of the One-Minute Paper." Active Learning in Higher Education, 6(2): 118-131.

Ulbig, Stacy G., and Fondren Notman. 2012. "Is Class Appreciation just a Click Away? Using Student Response System Technology to Enhance Shy Students' Introductory American Government Experience." Journal of Political Science Education, 8: 352-371.

Woody, William Douglas, David B. Daniel, and Crystal A. Baker. 2010. "E-books or Textbooks: Students Prefer Textbooks." Computers \& Education, 55: 945-948. 


\section{Appendix: Survey Instrument End of semester survey on course materials}

I am conducting a study about the materials used in the course PSCI 201: American Government. I invite you to participate in this research. You were selected as a possible participant because you are currently enrolled in this course. Please read this form and ask any questions you may have before agreeing to be in the study.

This study is being conducted by: Chelsea Kaufman, Ph.D., Assistant Professor of Political Science, Wingate University.

\section{Background Information:}

The purpose of this study is: to determine whether the materials used in this course are an affordable option to help students achieve the course leaming objectives.

\section{Procedures:}

If you agree to be in this study, I will ask you to do the following things: Complete a survey which will take approximately 5-10 minutes and grant me permission to compare your survey responses to your academic record.

Risks and Benefits of Being in the Study: There are no risks from participating in this study. Although responses will not remain anonymous, their confidentiality will be protected.

The direct benefits you for participating are: There are no direct benefits for participating in this study. Future students may benefit from the knowledge gained from the study results.

Confidentiality:

Research records will be kept in an encrypted file in the principal investigator's online file storage accounts (Microsoft OneDrive and Google Drive); I am the only person who will have access to the records. The data will be used for educational purposes and no information conceming individual students' education records will be shared.

Voluntary Nature of the Study:

Your participation in this study is entirely voluntary. Your decision whether or not to participate will not affect your current or future relations with any cooperating institutions or Wingate University. If you decide to participate, you are free to withdraw at any time without penalty.

Contacts and Questions

My name is Chelsea Kaufman, Ph.D. You may ask any questions you have now. If you have questions later, you may contact me at 704-233-8603. You may also contact the chairperson of the Wingate University Research Review Board at Irb@wingate.edu or at 704-233-8341 with any questions or concerns.

If you would like a copy of this form for your records, please let me know.

Statement of Consent:

I have read the above information. My questions have been answered to my satisfaction. I consent to participate in the study.

${ }^{*}$ Required 
1. Do you consent to participate in the study? *

Mark only one oval.

Yes

No Skip to "Did not consent."

\section{Verification of enrollment}

Please answer the following questions to verify your enrollment in the course

2. Please list your name. *

3. Please list your Wingate University email address. *

\section{Course enrollment}

Please indicate whether you agree or disagree with the following statements.

4. I enrolled in this course because it is a requirement.

Mark only one oval.

Strongly agree

Agree

Neutral

Disagree

Strongly Disagree

5. I enrolled in this course because the subject interests me.

Mark only one oval.

Strongly agree

Agree

Neutral

Disagree

Strongly Disagree

\section{Political interest}

Please indicate how often you do the following items in your daily life, when not required to for class. 
6. Follow news about politics and government Mark only one oval.

\section{Daily}

A few times a week

Weekly

Less than once a week

Never

7. Read blog posts about politics and government Mark only one oval.
Daily
Weekly
A few times a week
Less than once a week
Never

8. Read online news articles about politics and government Mark only one oval.
$\longrightarrow$ Daily
Weekly
A few times a week
Less than once a week
Never

9. Discuss politics and government with family or friends in person and/or on social media Mark only one oval.
$\longrightarrow$ Daily
A few times a week
Weekly
Less than once a week
Never

\section{Course materials preferences}

Please answer the following questions about your use of course materials.

10. When the option is available, do you generally prefer to purchase a print copy of course textbooks or the electronic version of course textbooks?

Mark only one oval.
Print copy
Electronic
N/A (i.e. never given option)
Other: 
11. Which of the following are reasons for this preference (print copy or electronic textbooks)? Check all that apply.

Check all that apply.

Ease of finding information in the text

$\square$ Ease of understanding the text

$\square$ Ease of reading the text

Ease of notetaking

$\square$ Price of the book

Other:

12. When purchasing textbooks, which option do you generally choose? Mark only one oval.

Buy a new print copy

Buy a used print copy

Rent a print copy

Buy an electronic copy

Rent an electronic copy

Share a copy with a classmate

I do not usually purchase, rent, or borrow textbooks

Other:

13. Have you ever decided not to purchase course materials due to their cost? Mark only one oval.

Yes

No

14. Have you previously taken another course requiring use of iClickers, the Reef app, or other inclass student response software?

Mark only one oval.

Yes

No

15. Which of the following do you prefer as options to engage with the course material in class? Check all that apply.

$\square$ Open class discussion

$\square$ None - prefer lecture over participation

$\square$ Surveys or polls

$\square$ Small group discussion

Games or simulations

Other:

\section{Use of course materials}


The following questions concern use of the course materials.

16. What percent of the course readings would you estimate that you read weekly? If you did not usually do the readings, enter " 0 "

17. Which of the following did you use the course readings for? Check all that apply Check all that apply.

$\square$ To prepare for lectures

To prepare for discussions

$\square$ To complete assignments

$\square$ To review for quizzes

To review for examinations

Other:

18. Did you ever reference the free online textbook that was linked as a resource in the course syllabus but was not assigned as a reading?

Mark only one oval.

Yes

No

19. Did you ever reference the free educational videos that were linked as a resource in the course syllabus but were not assigned for viewing?

Mark only one oval.

Yes

No

20. Did you use your clicker remote/app purchased for this course in any other courses this semester?

Mark only one oval.

Yes

No

\section{Assigned online readings}

Please indicate whether you agree or disagree with the following statements concerning the online readings assigned in this course. 
21. The readings were affordable

Mark only one oval.

Strongly agree

Agree

Neutral

Disagree

Strongly disagree

22. The readings were well-written

Mark only one oval.

Strongly agree

Agree

Deutral

Disagree

Strongly disagree

23. The readings were easy to understand

Mark only one oval.

Strongly agree

Agree

Neutral

Disagree

Strongly disagree

24. The information I needed for the course was easy to find within the readings Mark only one oval.

$\square$ Strongly agree
Agree
Neutral
$\square$ Disagree
Strongly disagree

25 . The readings clearly contained content written by experts on the topics Mark only one oval.

Strongly agree

Agree

Neutral

Disagree

Strongly disagree 
26. The readings helped me to engage with course material Mark only one oval.
Strongly agree
Agree
Neutral
Disagree
Strongly Disagree

27. The readings were up-to-date with current events Mark only one oval.

Strongly agree
Agree
Neutral
Disagree
Strongly disagree

28. I would recommend online readings be used instead of a traditional textbook in future courses.

Mark only one oval.

Strongly agree

Agree

Neutral

Disagree

Strongly disagree

\section{iClickers/Reef app}

Please indicate whether you agree or disagree with the following statements concerning the use of iClickers/the Reef app for polls in this course.

29. Considering the benefits I have been receiving from the clickers, the price was reasonable. Mark only one oval.

\section{Strongly agree}

Agree

Neutral

Disagree

Strongly disagree 
30. The clicker questions were helpful.

Mark only one oval.

Strongly agree
Agree
Neutral
Disagree
Strongly disagree

31. I was more likely to participate in the course because of the clickers. Mark only one oval.
Strongly agree
Agree
Neutral
Disagree
Strongly disagree

32. If I had a choice, I would get rid of the clickers. Mark only one oval.
Strongly agree
Agree
Neutral
Disagree
Strongly disagree

33. I would recommend the clickers be used in future courses. Mark only one oval.

Strongly agree

$\longrightarrow$ Agree

Neutral

$\longrightarrow$ Disagree

Strongly disagree

\section{Learning objectives}

Please indicate whether you agree or disagree with the following statements concerning the materials required for this course. 
34. The course readings helped me to understand the function of political institutions in the United States and how they have changed throughout history.

Mark only one oval.

Strongly agree

Agree

Neutral

Disagree

Strongly disagree

35. The course readings helped me to understand how forces such as societal and cultural changes, historical events, and political thought have shaped these institutions and their changes.

Mark only one oval.
Strongly agree
Agree
Neutral
Disagree
Strongly disagree

36. The course readings helped me to understand how the people interact with these institutions in the context of culture, history, and current events and policy debates.

Mark only one oval.
Strongly agree
$\longrightarrow$ Agree
$\longrightarrow$ Neutral
Disagree
Strongly disagree

\section{Course components and learning objectives}

The following question asks which course components did or did not students to achieve the course learning objectives. 
37. Please select which course components were MOST helpful to you in achieving these course objectives. Check all that apply.

Check all that apply.

$\square$ Final project assignment

$\square$ Examinations

$\square$ Weekly assignments

$\square$ Discussions

$\square$ Readings

$\square$ Polls

Minute papers

$\square$ Lectures

$\square$ Quizzes

38. Please select which course components were LEAST helpful to you in achieving these course objectives. Check all that apply.

Check all that apply.

$\square$ Discussions

$\square$ Lectures

$\square$ Examinations

$\square$ Quizzes

Readings

$\square$ Polls

$\square$ Weekly assignments

$\square$ Minute papers

$\square$ Final project assignment

\section{Overall satisfaction}

Please indicate whether you agree or disagree with the following statements concerning the materials required for this course.

39. I was generally satisfied with the materials for this course.

Mark only one oval.

Strongly agree
Agree
Neutral
Disagree
Strongly disagree


40. I would recommend these same materials be used for this course in the future. Mark only one oval.

Strongly agree

Agree

Neutral

Disagree

Strongly disagree

\section{Open-ended evaluation}

The following questions ask for open-ended responses evaluating the course materials.

41. What did you like best about the materials for this course?

42. What did you like least about the materials for this course?

43. Please add any comments or suggestions for changes or additions to these materials for use in future courses that were not otherwise addressed by this survey.

\section{Personal information}

Please answer the following questions about your personal characteristics. These will be used for demographic comparisons (i.e. to compare responses of younger and older students). 
44. Which of the following best describes your race? Check all that apply. Check all that apply.

White

Black or African American

American Indian or Alaska Native

$\square$ Asian

Native Hawaiian or Pacific Islander

$\square$ Don't know

$\square$ Don't know/Prefer not to say

Other:

45. Do you consider yourself Hispanic or Latino? Mark only one oval.

Yes

No

Don't know/Prefer not to say

46. Which of the following best describes your gender identity? Mark only one oval.

$\square$ Male
$\square$ Female
$\square$ Non-binary
$\square$ Prefer not to say

Other:

47. Did either of your parents complete a four-year university degree? Mark only one oval.

Yes, one parent

Yes, both parents

No, neither parent

Don't know

Prefer not to say 
48. What is your age?

Mark only one oval.

$18-24$

$25-34$

$35-44$

$45-54$

$55-64$

$65+$

Prefer not to say

49. How many hours per week are you employed during the semester? Mark only one oval.

0 (Not employed)

- $1-10$

$11-20$

$21-30$

$31-40$

More than 40

Prefer not to say

\section{End of survey}

Thank you for completing the survey! Click submit to record your responses. Please complete the followup survey which you will receive near the end of the semester.

Stop filling out this form.

\section{Did not consent}

You did not consent to participate in the study. You may now exit the survey.

Powered by

Google Forms: 


\section{Tables and Figures}

Table 1. Personal and Demographic Characteristics of Students

\begin{tabular}{|l|c|}
\hline Characteristic & Percent of Students (N) \\
\hline Non-Hispanic White & $68.4 \%(13)$ \\
\hline Female & $94.7 \%(18)$ \\
\hline First-generation college student & $52.6 \%(10)$ \\
\hline $18-24$ years old & $100 \%(19)$ \\
\hline Employed part-time & $47.4 \%(9)$ \\
\hline
\end{tabular}

Table 2. Academic Characteristics of Students

\begin{tabular}{|l|c|}
\hline Characteristic & Percent of Students (N) or Mean \\
\hline Political Science major or minor & $57.9 \%(11)$ \\
\hline Sophomore & $68.4 \%(13)$ \\
\hline Mean class absences & 4.26 \\
\hline Mean final course grade & 83.97 \\
\hline
\end{tabular}

Table 3. Evaluations of Course Readings and iClickers

\begin{tabular}{|l|c|}
\hline Statement & $\begin{array}{c}\text { Percent Agree/Strongly Agree } \\
\text { (N) }\end{array}$ \\
\hline The readings were easy to affordable & $79 \%(15)$ \\
\hline The readings were well-written & $84.2 \%(16)$ \\
\hline The readings were easy to understand & $63.1 \%(12)$ \\
\hline $\begin{array}{l}\text { The information I needed for the course } \\
\text { was easy to find within the readings }\end{array}$ & $79 \%(15)$ \\
\hline $\begin{array}{l}\text { The readings clearly contained content } \\
\text { written by experts on the topics }\end{array}$ & $79 \%(15)$ \\
\hline $\begin{array}{l}\text { The readings helped me to engage with } \\
\text { course material }\end{array}$ & $84.2 \%(16)$ \\
\hline $\begin{array}{l}\text { The readings were up-to-date with } \\
\text { current events }\end{array}$ & $84.2 \%(16)$ \\
\hline $\begin{array}{l}\text { Considering the benefits I have been } \\
\text { receiving from the clickers, the price } \\
\text { was reasonable }\end{array}$ & $79 \%(15)$ \\
\hline The clicker questions were helpful & $84.2 \%(16)$ \\
\hline $\begin{array}{l}\text { I was more likely to participate in the } \\
\text { course because of the clickers }\end{array}$ & $84.2 \%(16)$ \\
\hline $\begin{array}{l}\text { If I had a choice, I would get rid of the } \\
\text { clickers }\end{array}$ & $10.5 \%(2)$ \\
\hline
\end{tabular}


Table 4. Reasons for E-Book or Print Copy Preference

\begin{tabular}{|l|c|c|}
\hline \multicolumn{1}{|c|}{ Reason } & Electronic \% (N) & Print copy \% (N) \\
\hline Price & $36.8 \%(7)$ & $0 \%(0)$ \\
\hline Ease of finding information & $36.8 \%(7)$ & $42.1 \%(8)$ \\
\hline Ease of notetaking & $10.5 \%(2)$ & $47.4 \%(9)$ \\
\hline Not having to carry around & $5.3 \%(1)$ & $0 \%(0)$ \\
\hline $\begin{array}{l}\text { Ease of reading } \\
\text { information }\end{array}$ & $15.8 \%(3)$ & $42.1 \%(8)$ \\
\hline Ease of understanding & $0 \%(0)$ & $26.3 \%(5)$ \\
\hline
\end{tabular}

Table 5. Evaluation of Whether Readings Helped to Achieve Learning Objectives

\begin{tabular}{|l|c|}
\hline The course readings helped me to... & Percent Agree/Strongly Agree (N) \\
\hline $\begin{array}{l}\text { Understand the function of political } \\
\text { institutions in the US and how they have } \\
\text { changed throughout history. }\end{array}$ & $73.7 \%(14)$ \\
\hline $\begin{array}{l}\text { Understand how forces such as societal } \\
\text { and cultural changes, historical events, } \\
\text { and political thought have shaped these } \\
\text { institutions and their changes. }\end{array}$ & $84.2(16)$ \\
\hline $\begin{array}{l}\text { Understand how the people interact } \\
\text { with these institutions in the context of } \\
\text { culture, history, and current events and } \\
\text { policy debates. }\end{array}$ & $73.7 \%(14)$ \\
\hline
\end{tabular}




\section{Figure 1. LMS Announcement/Email Recruiting Students}

Extra Credit Survey!

Dear students:

I would like to determine whether the materials used in this course (the readings and clickers) are an affordable option to help you achieve the course learning objectives. To determine this, I am conducting a survey to learn your views on this topic.

All students who complete the survey will receive .5 percent extra credit towards their final course grade. If you do not wish to complete the survey, I will provide an equivalent extra credit opportunity in the form of a written assignment. Students may complete only one of these opportunities.

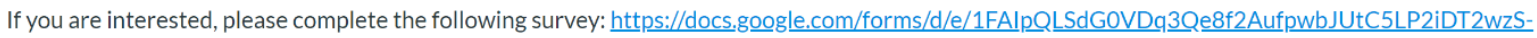

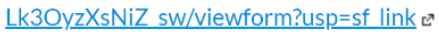

Please let me know if you have any questions,

Thank you,

Dr. Kaufman

\section{Figure 2. Use of Course Readings by Students}

\section{Which of the following did you use the course readings for? Check all that apply \\ 19 responses}

To prepare for lectures

To prepare for discussions

To complete assignments

To review for quizzes

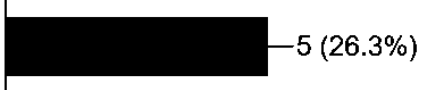

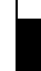

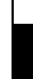

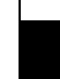

5 
Figure 3. Preferences for Engagement in Class

Which of the following do you prefer as options to engage with the course material in class?

19 responses

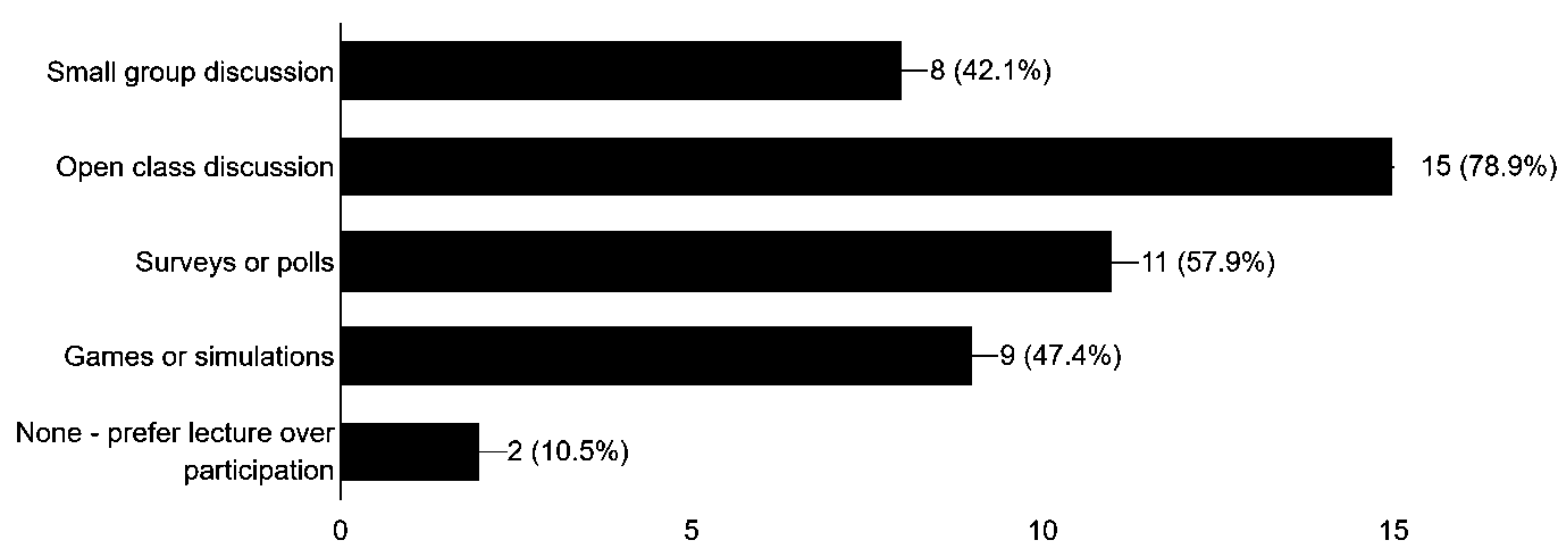


Figure 4. Correlations: Final Grades and Personal or Academic Characteristics

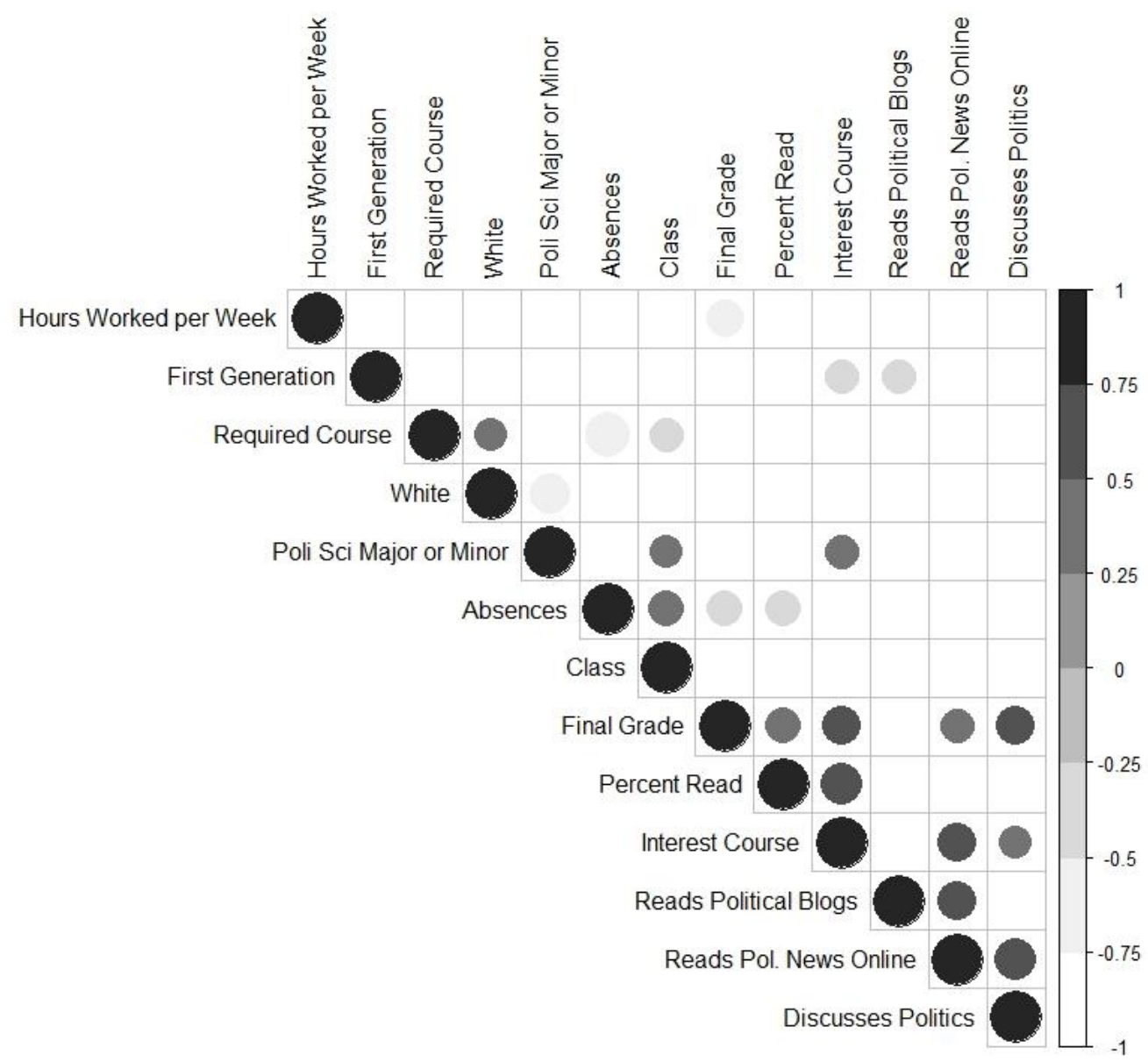


Figure 5. Most Helpful Course Components

Please select which course components were MOST helpful to you in achieving these course objectives. Check all that apply.

19 responses

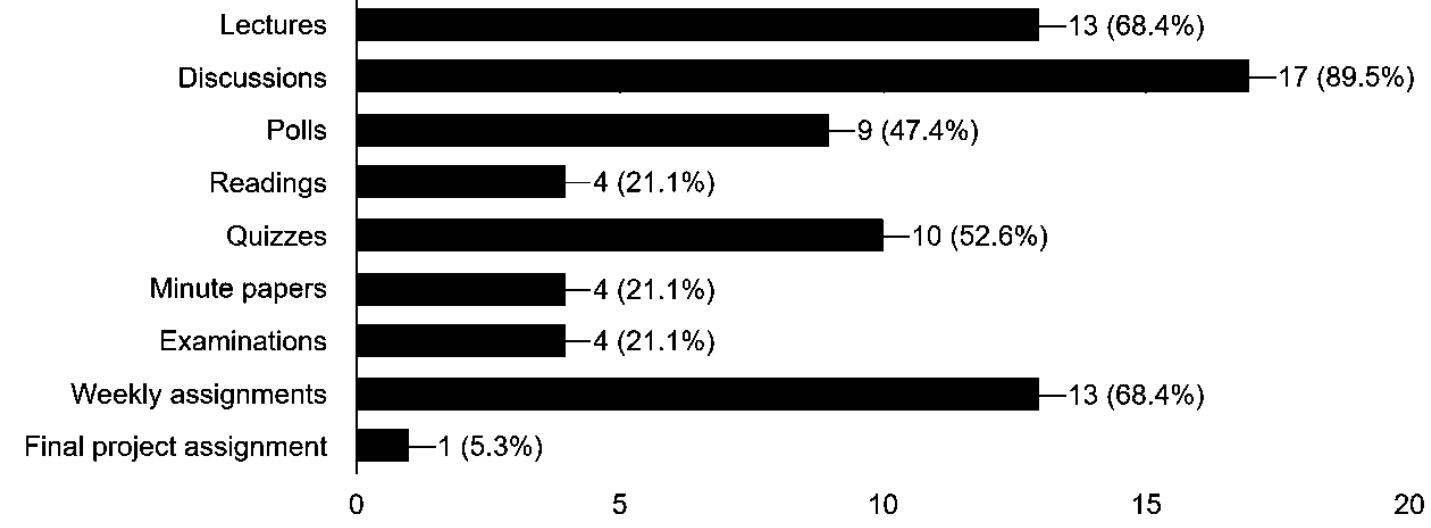

Figure 6. Least Helpful Course Components

Please select which course components were LEAST helpful to you in achieving these course objectives. Check all that apply.

19 responses

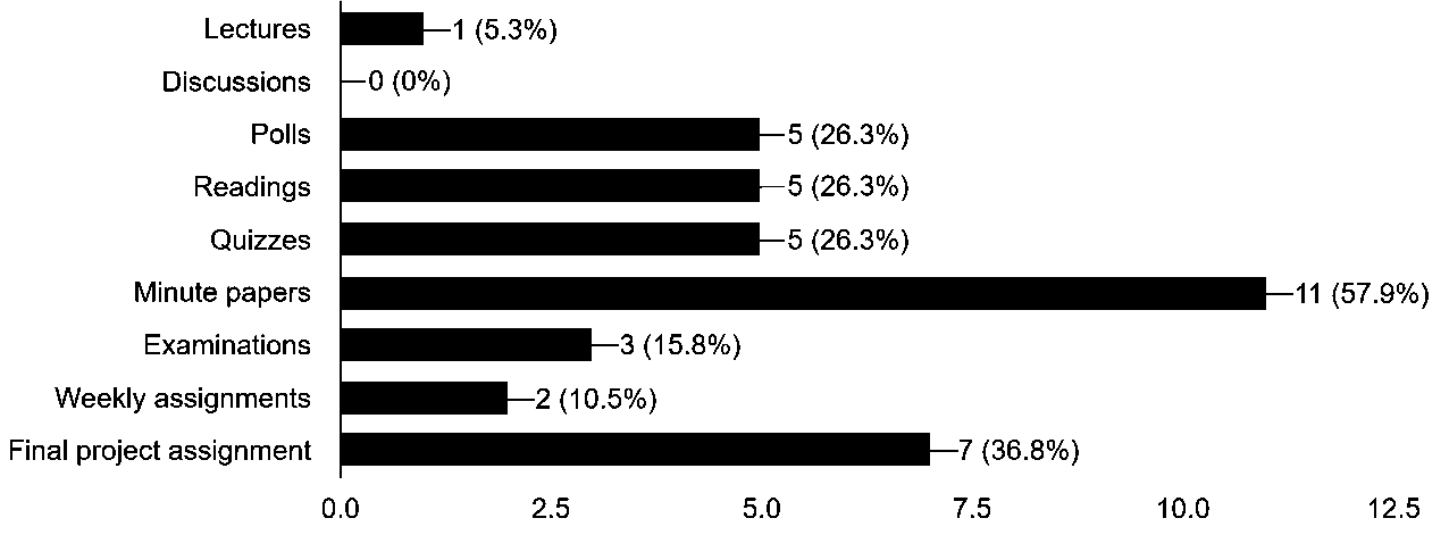


Figure 7. Correlations: Evaluation of Course Materials and Personal or Academic Characteristics

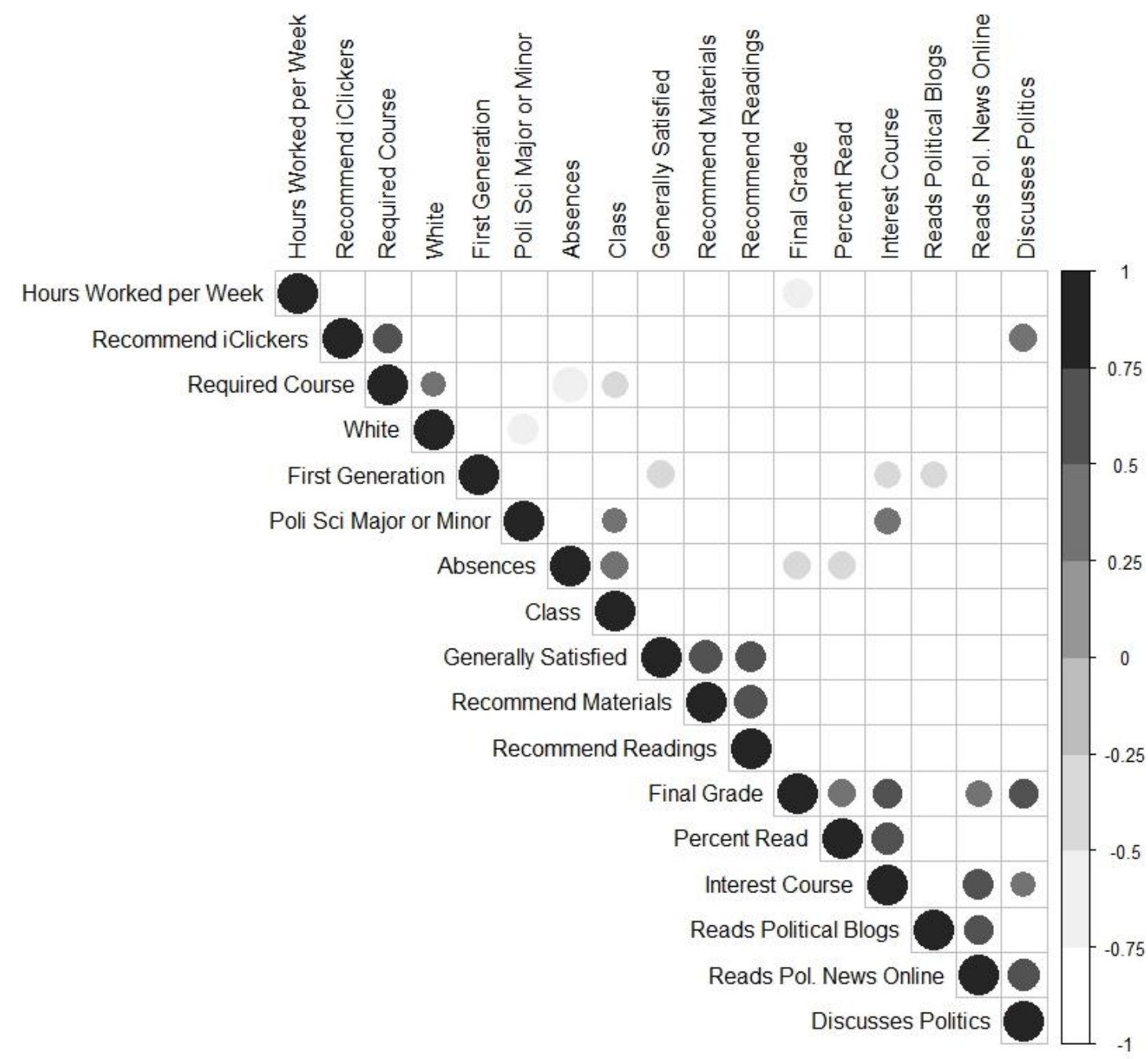


Figure 8. Correlations: Evaluation of Course Materials and Preferences for Course Materials and Engagement

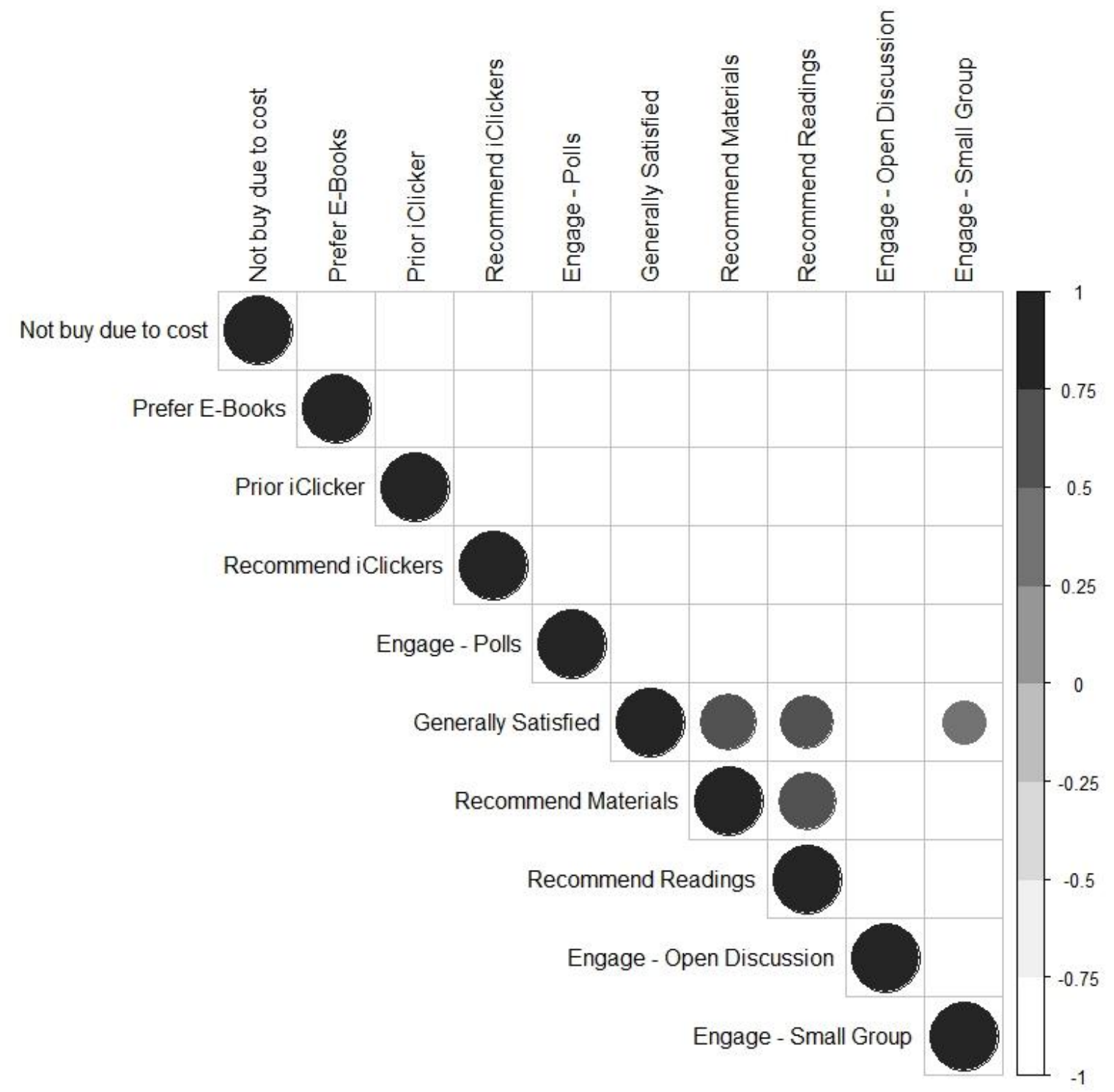

